\title{
Subcutaneous Nipple-Sparing Mastectomy and Immediate Breast Reconstruction
}

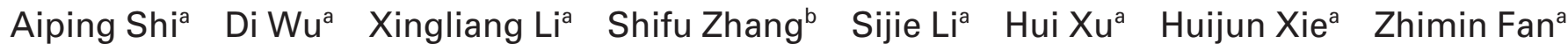 \\ ${ }^{a}$ Department of Breast Surgery, The First Hospital, Jilin University, Changchun, Jilin, \\ ${ }^{b}$ Department of General Surgery, Daqing Oilfields Hospital, Daqing, Heilongjiang, P.R. China
}

\section{Keywords}

Breast cancer . Immediate breast reconstruction . Mastectomy, nipple-sparing

\section{Summary}

Background: Without a doubt, nipple-sparing mastectomy affords a better cosmetic result than modified radical mastectomy. However, the surgical safety, radicality, complications, indications, and psychological benefits associated with this method are controversially discussed. Patients and Methods: We carried out a retrospective analysis of 35 patients (study group) who underwent nipple-sparing mastectomy between 2000 and 2008. Indications, incision selection, postoperative complications, recurrence, morbidity rate, and psychological status were recorded and assessed. Results: The survival outcome (5.7 vs. $6 \% ; p=0.35$ ) and complication rate (5.7 vs. $19 \% ; p=0.062$ ) of patients who underwent subcutaneous nipple-sparing mastectomy and immediate breast reconstruction with prosthesis were similar to those of patients who underwent modified radical mastectomy. Most patients in the study group were completely satisfied with the aesthetic results (immediately, $\mathrm{p}<0.001$; $<1$ year, $\mathrm{p}<0.001$; $>1$ year, $\mathrm{p}<0.001$ ), and no serious psychological disorders or stress were detected relative to patients with traditional mastectomy. Conclusion: Subcutaneous nipple-sparing mastectomy was beneficial and safe in this cohort of breast cancer patients. The approach is suitable for patients with isolated lesions located $\geq 2 \mathrm{~cm}$ from the nipple, as well as for patients with multiple lesions who are anxious about a good cosmetic appearance.

\section{Schlüsselwörter \\ Mammakarzinom - Sofortige Mammarekonstruktion . Mastektomie, brustwarzenerhaltend}

\section{Zusammenfassung}

Hintergrund: Zweifelsohne erzielt die brustwarzenerhaltende Mastektomie ein besseres kosmetisches Ergebnis als die modifizierte radikale Mastektomie. Chirurgische Sicherheit, Radikalität, Komplikationen, Indikationen und psychologische Vorteile der Methode werden jedoch kontrovers diskutiert. Patienten und Methoden: 35 Patienten (Studiengruppe), bei denen zwischen 2000 und 2008 eine brustwarzenerhaltende Mastektomie durchgeführt wurde, wurden retrospektiv analysiert. Indikationen, Wahl der Inzision, postoperative Komplikationen, Rezidive, Morbiditätsrate und psychologischer Status wurden aufgenommen und beurteilt. Ergebnisse: Hinsichtlich des Überlebens $(5,7$ vs. $6 \% ; p=0,35)$ und der Komplikationsrate $(5,7$ vs. $19 \% ; p=0,062)$ bestand kein Unterschied zwischen Patienten mit subkutaner brustwarzenerhaltender Mastektomie und sofortiger Mammarekonstruktion mittels Prothese und Patienten mit modifizierter radikaler Mastektomie. Die meisten Patienten in der Studiengruppe waren mit dem ästhetischen Ergebnis vollkommen zufrieden (sofort, $\mathrm{p}<0,001$; $<1$ Jahr, $\mathrm{p}<0,001 ;>1$ Jahr, $\mathrm{p}<0,001$ ), und verglichen mit Patienten mit einer traditionellen Mastektomie wurden keine ernsten psychologischen Erkrankungen oder Stress beobachtet. Schlussfolgerung: In unserer Studiengruppe war die subkutane brustwarzenerhaltende Mastektomie eine positive und sichere Maßnahme. Die Methode ist für Patienten mit isolierten, $\geq 2 \mathrm{~cm}$ von der Brustwarze entfernten Läsionen sowie für Patienten mit multiplen Läsionen, denen ein gutes kosmetisches Erscheinungsbild sehr wichtig ist, geeignet.

\section{KARGER \\ Fax +497614520714 \\ Information@Karger.de}

www.karger.com (c) 2012 S. Karger GmbH, Freiburg

1661-3791/12/0072-0131\$38.00/0

Accessible online at:

www.karger.com/brc
Zhimin Fan, M.D

Department of Breast Surgery

The First Hospital, Jilin University

No. 71 Xinminda Road, Changchun, Jilin 130021, P.R. China.

Tel./Fax +86 43188782283

fanzhimn@public.cc.jl.cn 


\section{Introduction}

Breast cancer is the most common cause of death in adult women [1]. The incidence increases year by year, and there is a trend for younger individuals to be affected at an increasing rate. The 5-year survival rates of patients with TNM stage $0-\mathrm{I}$ and II are 96.8 und $73.7 \%$, respectively [2]. Following modified radical mastectomy, disfigurement of the chest wall may severely affect a patient's quality of life. As a result, some young patients refuse to undergo this procedure, even though it provides a potential cure in the early stages of breast cancer. In recent years, breast reconstruction has been required in a significant proportion of patients with breast cancer [3, 4]. Although breast conservation has been accepted worldwide, the proportion of breast-conserving mastectomies performed accounted for less than $10 \%$ of the total amount of mastectomies in China between the years of 2001 and 2004. This figure is greater than $50 \%$ in America, $70-80 \%$ in Singapore, and $60 \%$ in Japan [5]. Because doctors and patients are concerned with recurrence due to residual mammary tissue, en bloc resection of the mammary gland is often performed, with radio-

Table 1. Clinical demographics of patients

\begin{tabular}{|c|c|c|}
\hline & $\begin{array}{l}\text { Study group } \\
(\mathrm{n}=35)\end{array}$ & $\begin{array}{l}\text { Control group } \\
(\mathrm{n}=100)\end{array}$ \\
\hline \multirow[t]{2}{*}{ Age, median, years } & 35.6 & 50.8 \\
\hline & \multicolumn{2}{|l|}{ Patients, n (\%) } \\
\hline \multicolumn{3}{|l|}{ Location } \\
\hline Left & $13(37.1)$ & $58(58.0)$ \\
\hline Right & $20(57.1)$ & $39(39.0)$ \\
\hline Bilateral & $2(5.7)$ & $3(3.0)$ \\
\hline Multifocal & $3(8.6)$ & $5(5.0)$ \\
\hline \multicolumn{3}{|l|}{ Tumor size } \\
\hline $\mathrm{T} 1$ & $14(40.0)$ & $34(34.0)$ \\
\hline $\mathrm{T} 2$ & $19(54.3)$ & $62(62.0)$ \\
\hline $\mathrm{T} 3$ & $2(5.7)$ & $4(4.0)$ \\
\hline \multicolumn{3}{|l|}{ Clinical stage } \\
\hline I & $12(34.3)$ & $28(28.0)$ \\
\hline II & $18(51.4)$ & $63(63.0)$ \\
\hline III & $5(14.3)$ & $9(9.0)$ \\
\hline \multicolumn{3}{|l|}{ Pathology } \\
\hline Intraductal carcinoma & 2 & 7 \\
\hline Intralobular carcinoma & 0 & 1 \\
\hline Microinvasive ductal carcinoma & 0 & 8 \\
\hline Microinvasive lobular carcinoma & 0 & 2 \\
\hline Invasive ductal carcinoma & $28(80.0)$ & $55(55.0)$ \\
\hline Invasive lobular carcinoma & 1 & 8 \\
\hline \multicolumn{3}{|l|}{ Special pathological type } \\
\hline Mucinous adenocarcinoma & 2 & 5 \\
\hline Medullary carcinoma & 1 & 8 \\
\hline Comedocarcinoma & 0 & 1 \\
\hline Cribriform cacinoma & 0 & 1 \\
\hline Paget's disease & 0 & 2 \\
\hline Cystosarcoma phyllodes & 1 & 1 \\
\hline \multicolumn{3}{|l|}{ Estrogen receptor } \\
\hline Positive & $25(71.4)$ & $62(62.0)$ \\
\hline Negative & $10(28.6)$ & $38(38.0)$ \\
\hline \multicolumn{3}{|l|}{ Progesterone receptor } \\
\hline Positive & $18(51.4)$ & $54(54.0)$ \\
\hline Negative & 17 (48.6) & $46(46.0)$ \\
\hline \multicolumn{3}{|l|}{ HER-2 } \\
\hline Positive & $16(45.7)$ & $37(37.0)$ \\
\hline Negative & $19(54.3)$ & $63(63.0)$ \\
\hline
\end{tabular}

therapy offering optimal postoperative treatment. However, not all patients are candidates for conservative surgery. Exclusion criteria include diffuse, suspicious, or malignant-appearing microcalcifications as detected by mammography, widespread disease, tumors $\geq 3 \mathrm{~cm}$, and positive pathologic margins. As the treatment of patients with breast cancer is based on clinical data of both the patient and the existing lesions, subcutaneous nipple-sparing mastectomy with immediate breast reconstruction (IBR) has emerged as an alternative approach to breast conservation and can be employed following failure of breast-conserving surgery [6]

\section{Materials and Methods}

\section{Study Group and Control Group}

We performed a retrospective analysis of 35 patients who were treated with subcutaneous nipple-sparing mastectomy and IBR between 2000 and 2008. 100 patients randomly selected as the control group underwent modified radical mastectomy during the same time interval. Table 1 exhibits the clinical demographics of the patients in both groups. The study was approved by the ethics committee of The First Hospital of Jilin University, and informed consent was obtained from all patients. Breast cancer was confirmed using pathological methods, and cases with evidence of distant metastasis were excluded from the study. Some patients preferred one surgical approach over the other for aesthetic reasons. Intraoperative biopsies of mammary gland specimens resected from below the nipple-areola complex (NAC) confirmed that both the NAC and the skin were not cancerous. None of the patients suffered from other life-threatening or chronic diseases, such as ischemic heart disease, hypertension, chronic pulmonary diseases, diabetes mellitus, or polyvalent allergies. Likewise, patients in the control group did not have distant metastases or other diseases. All patients in the control group were assigned to undergo radical modified mastectomy between 2000 and 2008 .

\section{Surgery}

Preoperative preparation included the assessment of breast volume to determine the size of the prosthesis. A combination of epidural and general anesthesia was used for the procedure. 3 types of incision were used: an S-shaped incision ending at the inferior border of the breast parallel to the areola (figs. 1 and 2), a fusiform incision with a radial incision to the areola extending in the direction of the axilla on the lateral breast (fig. 3), and an arc-shaped incision parallel to the axillary folds as made for mastoscopy (fig. 4). Following en bloc tumor removal, a pathological examination was performed to determine the pathological TNM stage and ensure that the cancerous tissue had been completely removed. The breast skin was then moved upward to the inferior clavicle margin and downward to the superior border of rectus abdominis, internal to the parasternal line and external to the leading edge of the latissimus dorsi muscle. The fascia was peeled from the surface of the pectoralis major muscle, and the prosthesis was implanted between the pectoralis major and pectoralis lesser. Axillary fat and lymph nodes were removed. The prosthesis and drainage tubes were placed, and the skin was sutured. In addition to surgery, patients in both groups received adjuvant treatment as recommended by the National Comprehensive Cancer Network (NCCN) guidelines [7], including chemotherapy regimens consisting of FAC (5-fluorouracil + adriamycin + cyclophosphamide), TAC (taxol + adriamycin + cyclophosphamide), or CMF (cyclophosphamide + methotrexate +5 -fluorouracil). Radiotherapy with a total dose of $50 \mathrm{~Gy}$ in 25 fractions was optimal for all patients in the study group, and it was up to the senior physician to determine whether or not postoperative radiotherapy was warranted. In the control group, patients with tumors $\geq 3 \mathrm{~cm}$ in 


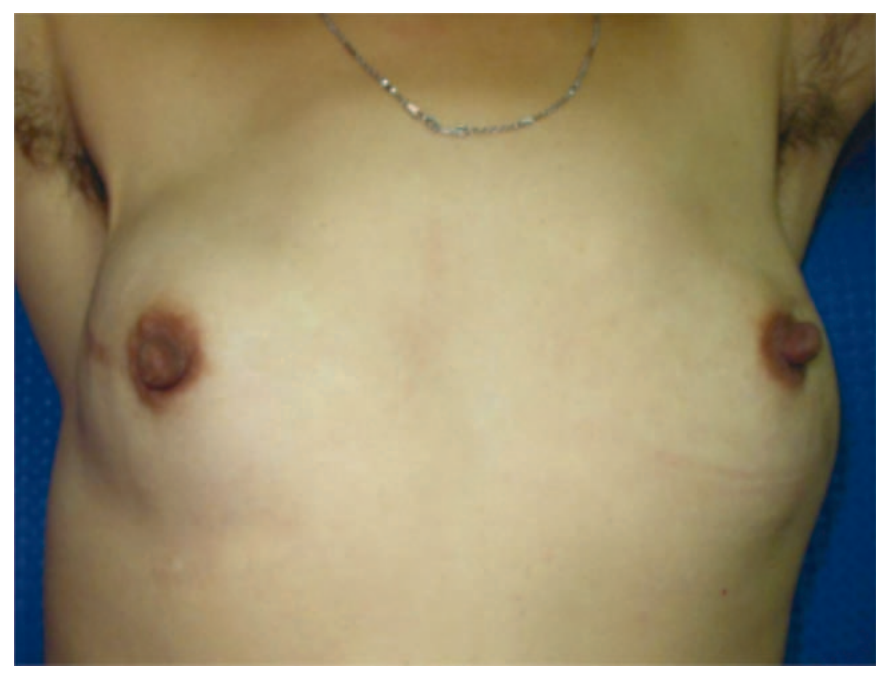

Fig 1. Bilateral breast cancer (stage I) 60 months after reconstruction with implant.

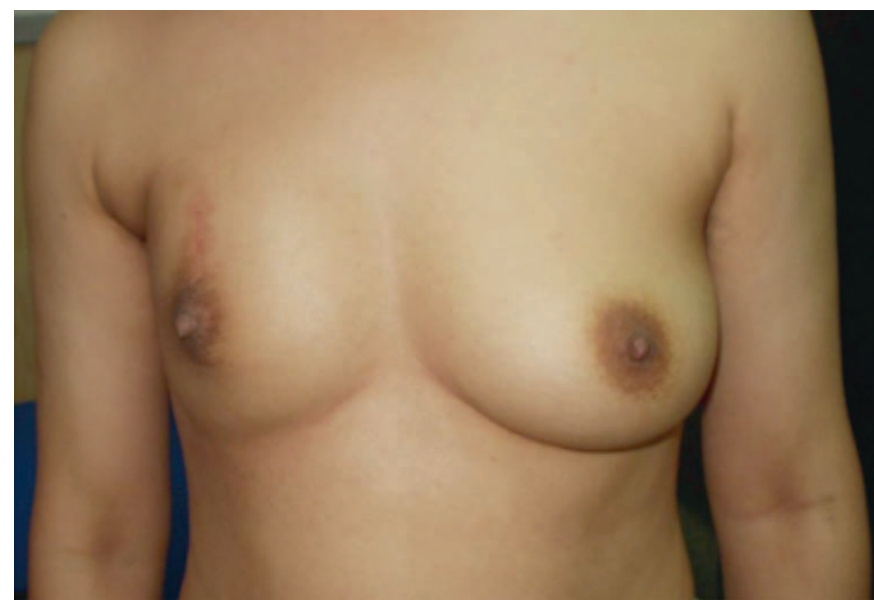

Fig 3. Right breast cancer (stage I) 24 months after reconstruction with implant (fusiform incision above the tumor with radial incision to the areola).

diameter and metastatic axillary lymph nodes were treated with radiotherapy. Hormonal therapy was indicated for estrogen receptor-positive and/or progesterone receptor-positive patients (table 1).

\section{Follow-Up}

Follow-up was performed over the telephone or during an outpatient clinic visit. All patients were followed up over the course of 10-104 months. The median follow-up time was 68 months. All patients were evaluated once a year, and clinical data were collected over the telephone or during outpatient clinic visits. In total, 23 patients were followed for more than 54 months.

\section{Statistical Methods}

Statistical analysis was performed using SPSS 18.0 (SPSS Inc., Chicago, IL, USA). An $\chi^{2}$ test was performed, and the log-rank test was applied to compare survival. A $\mathrm{p}$ value $\leq 0.05$ was considered statistically significant.

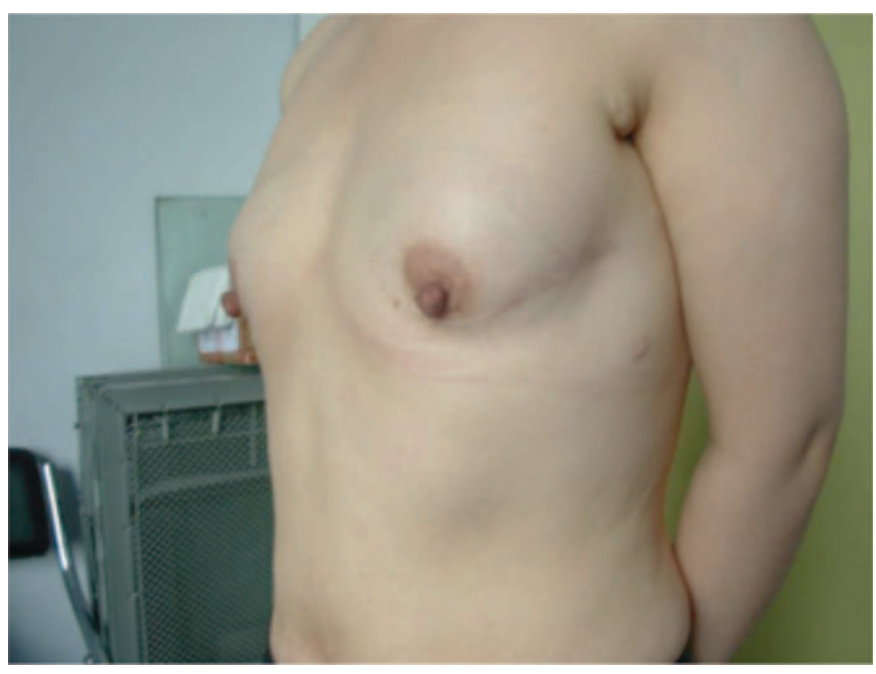

Fig 2. Side view of the S-form incision.

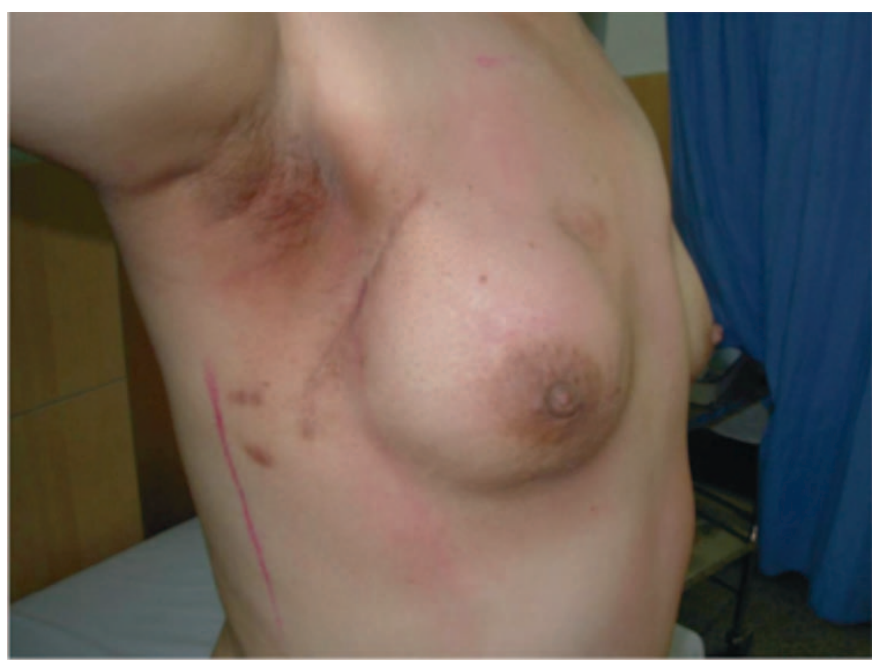

Fig 4. Right breast cancer 12 months after reconstruction using endoscope-assisted axillary incision which is not visible.

\section{Results}

As shown in table 2, following surgery, 2 patients presented with seroma and infection, and 1 patient suffered from hematoma and infection. Seroma and flap necrosis occurred in 4 patients. There was no significant difference between the study group and the control group in terms of surgical rate of postoperative complications, local relapse, or distant metastasis.

Poor outcomes were correlated with age and axillary lymph node metastasis, and were not related to the surgical approach (table 3). Patients receiving breast reconstruction in our study were more satisfied with the postsurgical aesthetic appearance compared to those in the control group (table 4). The patients with subcutaneous nipple-sparing mastectomy and 
IBR had higher levels of self-confidence as well as social and sexual activity than those who had undergone modified radical mastectomy. Psychological disorders in the study group were less common than in the control group (table 5). Implantation of a prosthesis prolonged the surgical time by only 17 min on average (table 6).

The median follow-up time was 68 months (range 10-104 months), and no severe complications were observed in either group. There was no significant difference detected in the clinicopathologic data between both groups. $94.3 \%$ of the patients were satisfied with the aesthetic outcome following breast reconstruction. Moreover, in the study group, 33 patients $(94.3 \%)$ were still alive at the end of the study.

Two patients in the study group had local recurrence; 1 had supraclavicular lymph node metastasis and the other presented with metastatic lesions in the areola area and the NAC 4 years after she had refused postoperative radiotherapy and was treated only with CMF chemotherapy and hormonal therapy. Both patients survived the recurrence. 2 patients in the study group had distant metastasis; 1 patient with involved axillary lymph nodes presented with lung and bone metasta-

Table 2. Postoperative complications, recurrence, and morbidity rate

\begin{tabular}{llll}
\hline Complications & \multicolumn{2}{l}{ Patients, $\mathrm{n}(\%)$} & $\mathrm{p}$ \\
\cline { 2 - 3 } & $\begin{array}{l}\text { study group } \\
(\mathrm{n}=35)\end{array}$ & $\begin{array}{l}\text { control group } \\
(\mathrm{n}=100)\end{array}$ & \\
\hline Seroma & $1(2.9)$ & $14(14.0)$ & $0.135^{\mathrm{a}}$ \\
Hematoma & $0(0.0)$ & $2(2.0)$ & $1.000^{\mathrm{b}}$ \\
Flap necrosis & $2(5.7)$ & $7(7.0)$ & $1.000^{\mathrm{a}}$ \\
Infection & $2(5.7)$ & $3(3.0)$ & $0.832^{\mathrm{a}}$ \\
Total complications & $2(5.7)$ & $19(19.0)^{*}$ & $0.062^{\mathrm{a}}$ \\
Local relapse & $2(5.7)$ & $5(5.0)$ & $1.000^{\mathrm{a}}$ \\
Metastasis & $2(5.7)$ & $7(7.0)$ & $1.000^{\mathrm{a}}$ \\
Deaths & $2(5.7)$ & $6(6.0)$ & $0.350^{\mathrm{c}}$ \\
\hline${ }^{\mathrm{a}} \chi^{2}$ test. & & \\
${ }^{\mathrm{b}}$ Fisher's exact probability test. & & \\
${ }^{\mathrm{c}}$ Log-rank test. & & & \\
\hline
\end{tabular}

ses 9 months after surgery, and 1 patient with 10 involved axillary lymph nodes died of multiple organ metastases 2 years following surgery. Compared with the randomly selected patients treated with modified radical mastectomy, there were no statistically significant differences in the rates of distant metastasis, recurrence, or death.

\section{Discussion}

NAC-sparing surgery is associated with better cosmetic outcome compared to modified radical mastectomy [8]. Subcutaneous mastectomy that spares the NAC plus IBR has been advocated for patients with early-stage breast cancer [9]. However, many surgeons and patients are concerned about potential relapse and resectability [10]. Unfortunately, some mammary tumors are still difficult to completely resect despite the choice of mastectomy procedures. According to recent studies [11-13], relapse rate and resectability are similar between traditional modified radical mastectomy and NACsparing mastectomy.

In our 35 cases with subcutaneous nipple-sparing mastectomy and IBR, the prosthesis had translocated upward in 2 cases of which 1 required removal of the implant because of severe infection. All of the others had good cosmetic outcomes with satisfaction rates of $94.3 \%$. The incidences of subcutaneous edema and hemorrhage were significantly lower in the study group compared to the control group. However, subcutaneous infection was more common in the study group, although this trend did not reach statistical significance. 1 patient who presented with a positive sentinel lymph node received a second surgery with a second pathological examination to confirm the diagnosis. Regardless of the surgical procedure, the number of operations is an independent factor for infection [14]. As surgical techniques and instruments improve, infection rates are gradually declining $[14,15]$. Compared with the latissimus dorsi and rectus abdominis flap,

Table 3. Outcome of 13 patients with recurrence and metastases

\begin{tabular}{|c|c|c|c|c|c|c|c|c|c|}
\hline Group & $\begin{array}{l}\text { Age, } \\
\text { years }\end{array}$ & TNM & ER & PR & HER-2 & $\begin{array}{l}\text { Adjuvant } \\
\text { treatment }\end{array}$ & Metastasis location & $\begin{array}{l}\text { TTR, } \\
\text { months }\end{array}$ & Status \\
\hline Study & 21 & $\mathrm{~T} 2 \mathrm{~N} 2 \mathrm{M} 0$ & positive & negative & positive & $\mathrm{CMF}+\mathrm{R}+\mathrm{H}$ & lung and bone & 9 & dead \\
\hline Study & 29 & $\mathrm{~T} 1 \mathrm{~N} 3 \mathrm{M} 0$ & negative & positive & positive & $\mathrm{CAF}+\mathrm{R}$ & liver & 11 & dead \\
\hline Study & 30 & T2N0M0 & positive & positive & negative & $\mathrm{CMF}+\mathrm{R}+\mathrm{H}$ & supraclavicular & 72 & alive \\
\hline Study & 34 & T2NOMO & negative & positive & negative & $\mathrm{CMF}+\mathrm{H}$ & areola-nipple complex & 48 & alive \\
\hline Control & 47 & $\mathrm{~T} 2 \mathrm{~N} 2 \mathrm{M} 0$ & negative & negative & positive & $\mathrm{ATC}+\mathrm{R}+\mathrm{H}$ & brain & 20 & dead \\
\hline Control & 54 & $\mathrm{~T} 2 \mathrm{~N} 1 \mathrm{M} 0$ & negative & negative & positive & $\mathrm{CAF}+\mathrm{H}$ & bone & 14 & dead \\
\hline Control & 51 & $\mathrm{~T} 2 \mathrm{~N} 1 \mathrm{M} 0$ & positive & positive & negative & $\mathrm{CAF}+\mathrm{R}+\mathrm{H}$ & bone and liver & 17 & dead \\
\hline Control & 50 & T2N0M0 & negative & negative & positive & $\mathrm{C}+\mathrm{R}+\mathrm{H}$ & supraclavicular & 29 & alive \\
\hline Control & 53 & $\mathrm{~T} 1 \mathrm{~N} 1 \mathrm{M} 0$ & negative & positive & negative & $\mathrm{CMF}+\mathrm{R}$ & supraclavicular & 24 & alive \\
\hline Control & 34 & T2N0M0 & negative & negative & positive & $\mathrm{CMF}+\mathrm{R}+\mathrm{H}$ & supraclavicular & 15 & dead \\
\hline Control & 34 & $\mathrm{~T} 2 \mathrm{~N} 1 \mathrm{M} 0$ & positive & negative & positive & $\mathrm{TAC}+\mathrm{H}$ & chest wall & 18 & dead \\
\hline Control & 67 & $\mathrm{~T} 2 \mathrm{~N} 1 \mathrm{M} 0$ & negative & negative & positive & $\mathrm{CMF}$ & chest wall & 30 & alive \\
\hline
\end{tabular}

$\mathrm{ER}=$ Estrogen receptor; $\mathrm{PR}=$ progesterone receptor; $\mathrm{TTR}=$ time to recurrence; $\mathrm{H}=$ hormone therapy; $\mathrm{R}=$ radiotherapy; $\mathrm{C}=$ chemotherapy; $\mathrm{CMF}=$ cyclophosphamide, methotrexate, fluorouracil; CAF $=$ cyclophosphamide, adriamycin, fluorouracil; $\mathrm{ATC}=$ adriamycin $\rightarrow$ taxol $\rightarrow$ cyclophosph amide; TAC = taxol, adriamycin, cyclophosphamide. 
Table 4. Local aesthetic satisfaction

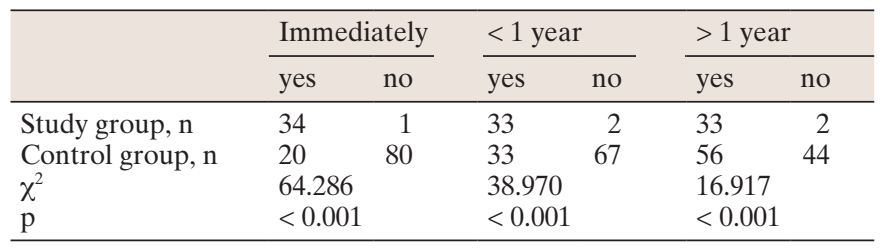

Table 5. Psychological status

\begin{tabular}{|c|c|c|c|c|c|c|c|c|c|c|}
\hline & \multicolumn{2}{|c|}{ Social activity } & \multicolumn{2}{|c|}{ Pressure } & \multicolumn{2}{|c|}{ Emotion worse } & \multicolumn{2}{|c|}{ Confidence } & \multicolumn{2}{|c|}{ Sexual satisfaction } \\
\hline & yes & no & yes & no & yes & no & yes & no & yes & no \\
\hline Study group & 35 & 0 & 4 & 31 & 0 & 35 & 33 & 2 & 31 & 4 \\
\hline Control group & 60 & 40 & 41 & 59 & 9 & 91 & 30 & 70 & 82 & 18 \\
\hline$\chi^{2}$ & 19.895 & & 10.202 & & 2.084 & & 40.504 & & 0.410 & \\
\hline $\mathrm{p}$ & $<0.001$ & & 0.001 & & 0.149 & & $<0.001$ & & 0.522 & \\
\hline
\end{tabular}

Table 6. Surgical time (mean \pm standard deviation)

\begin{tabular}{lllll}
\hline & Study $(\mathrm{n}=35)$ & Control $(\mathrm{n}=100)$ & $\mathrm{t}$ & $\mathrm{p}$ \\
\hline Time, $\min$ & $125.86 \pm 14.394$ & $108.73 \pm 13.510$ & 6.154 & $<0.001$ \\
\hline
\end{tabular}

prosthesis implantation is simpler and less time-consuming, and thus a more suitable choice for IBR [16].

In traditional radical mastectomy, modified radical mastectomy, or skin-conserving radical mastectomy, $20 \%$ of the mammary gland is retained [17]. Several studies have reported no significant difference in recurrence rates among the surgical approaches. Gerber et al. [10] compared patients who underwent NAC-conserving surgery to patients treated with radical mastectomy, and found that the former exhibited lower complication rates and more satisfactory cosmetic results. As long as the tumor was $\geq 2 \mathrm{~cm}$ from the areola, the recurrence rate was not affected. Hence, breast-conserving surgery appears to be a safe and reliable method of tumor treatment. In our study, only a small number of patients with a relatively short follow-up period were included, and conclusions concerning the operational safety should therefore be drawn with care.

As a technique, subcutaneous nipple-sparing mastectomy allowed resection of almost all of the breast parenchyma and skin overlying or adjacent to invasive carcinoma. The traditional incision [18] used for subcutaneous nipple-sparing mastectomy is a circumareolar incision with lateral extension to include an upper outer quadrant biopsy site. A separate incision may be necessary for resecting local tumor and skin overlying the tumor site, although this is not optimal due to visible scarring (figs. 1-3).

Endoscopy offers several advantages, such as the presence of a clear visual field, making it useful for subcutaneous nipple-sparing mastectomy [19]. The incision is made only in the lateral axilla and is used for resection of the mammary gland, axillary dissection, and insertion of the saline-filled prosthesis. The average incision length in our cohort was $7 \mathrm{~cm}$, and patient satisfaction was increased (fig. 4).

IBR by prosthesis implantation is a simple and suitable approach for breast reconstruction. Either a synthetic implant or the patient's own tissue, including musculocutaneous flaps, are used for reconstruction. Implantation of the prosthesis took very little time, and on average lengthened the total surgery time by only $17 \mathrm{~min}$, as compared to no prosthesis implantation. The patients in the study group, who received breast reconstruction, felt more satisfied with the resultant aesthetic appearance than those in the control group. Psychologically, they had higher levels of social and sexual activity than patients who underwent radical mastectomy based on our observations. Breast reconstruction is successful in maintaining patients' self-confidence post surgery.

\section{Acknowledgement}

This work was supported by the fund of Réseau de lutte au cancer de rUniversité Norman-Bethune (Project PSCLU 010-282/19156).

\section{Disclosure Statement}

There are no financial or other interests with regard to this paper that might be considered as a conflict of interest. 


\section{References}

1 Jemal A, Bray F, Center MM, Ferlay J, Ward E, Forman D: Global cancer statistics. CA Cancer J Clin 2011;61:69-90.

2 Yang MT, Rong TH, Huang ZF, Zeng CG, Long $\mathrm{H}, \mathrm{Fu} \mathrm{JH}$, Lin $\mathrm{P}$, Wang $\mathrm{X}$, Wang SY, Wang X, Tang J: (Clinical analysis of resectable breast cancer: a report of 6,263 cases). Ai Zheng 2005;24:327-331.

3 Reddy S, Colakoglu S, Curtis MS, Yueh JH Ogunleye A, Tobias AM, Lee BT: Breast cancer recurrence following postmastectomy reconstruction compared to mastectomy with no reconstruction. Ann Plast Surg 2011;66:466-471.

$\checkmark 4$ Malata CM, McIntosh SA, Purushotham AD: Immediate breast reconstruction after mastectomy for cancer. Br J Surg 2000;87:1455-1472.

5 Eriksen C, Frisell J, Wickman M, Lidbrink E, Krawiec K, Sandelin K: Immediate reconstruction with implants in women with invasive breast cancer does not affect oncological safety in a matched cohort study. Breast Cancer Res Treat 2011;127:439446.

-6 Sharma R, Rourke LL, Kronowitz SJ, Oh JL, Lucci A, Litton JK, Robb GL, Babiera GV, Mittendorf EA, Hunt KK, Kuerer HM: Management of local-regional recurrence following immediate breast reconstruction in patients with early breast cancer treated without postmastectomy radiotherapy. Plast Reconstr Surg 2011;127:17631772.

7 Rose VL: NCCN and ACS collaborate on a patient's version of the NCCN practice guidelines for breast cancer. National Comprehensive Cancer Network. American Cancer Society. Am Fam Physician 1999;60:2169-2170.
Didier F, Radice D, Gandini S, Bedolis R, Rotmensz N, Maldifassi A, Santillo B, Luini A, Galimberti V, Scaffidi E, Lupo F, Martella S, Petit JY: Does nipple preservation in mastectomy improve satisfaction with cosmetic results, psychological adjustment, body image and sexuality? Breast Cancer Res Treat 2009;118:623-633.

$\checkmark 9$ Chen JJ, Chen JY, Yang BL, Di GH, Shao ZM, Wu J: Oncological safety and satisfaction in earlystage breast cancer patients treated with immediate autologous breast reconstruction after skin-sparing mastectomy in a Chinese population. Breast 2011;20:S51-S51.

10 Gerber B, Krause A, Dieterich M, Kundt G, Reimer T: The oncological safety of skin sparing mastectomy with conservation of the nipple-areola complex and autologous reconstruction: an extended follow-up study. Ann Surg 2009;249:461-468.

11 Isern AE, Manjer J, Malina J, Loman N, Martensson T, Bofin A, Hagen AI, Tengrup I, Landberg G, Ringberg A: Risk of recurrence following delayed large flap reconstruction after mastectomy for breast cancer. Brit J Surg 2011; 98:659-666.

12 Kennedy MJ, Abeloff MD: Management of locally recurrent breast cancer. Cancer 1993;71:2395-2409.

13 Barton FE, English JM, Kingsley WB, Fietz M: Glandular excision in total glandular mastectomy and modified radical mastectomy - a comparison. Plast Reconstr Surg 1991;88:389-392.

14 Zhang ZT, Zhang HW, Fang XD, Wang LM, Li XX, Li YF, Sun XW, Carver J, Simpkins D, Shen J, Weisberg M: Cosmetic outcome and surgical site infection rates of antibacterial absorbable (Polyglactin 910) suture compared to Chinese silk suture in breast cancer surgery: a randomized pilot research. Chin Med J (Engl) 2011;124:719-724.
5 Penel N, Yazdanpanah Y, Chauvet MP, Clisant S, Giard S, Neu JC, Lefebvre D, Fournier C, Bonneterre J: Prevention of surgical site infection after breast cancer surgery by targeted prophylaxis antibiotic in patients at high risk of surgical site infection. J Surg Oncol 2007;96:124-129; Erratum in J Surg Oncol 2008;97:479-479.

16 Jiang HC, Miao R: Advances in breast reconstruction following breast cancer surgery. Chin J Bases Clin Gen Surg 2010;(12):1221-1224.

17 Huang O, Wang LP, Shen KW, Lin H, Hu Z, Liu GY, Wu J, Lu JS, Shao ZM, Han OX, Shen ZZ: Breast cancer subpopulation with high risk of internal mammary lymph nodes metastasis: analysis of 2,269 Chinese breast cancer patients treated with extended radical mastectomy. Breast Cancer Res Treat 2008;107:379-387.

18 Toth BA, Lappert P: Modified skin incisions for mastectomy - the need for plastic surgical input in preoperative planning. Plast Reconstr Surg 1991;87:1048-1053.

19 Kitamura K, Ishida M, Inoue H, Kinoshita J, Hashizume M, Sugimachi K: Early results of an endoscope-assisted subcutaneous mastectomy and reconstruction for breast cancer. Surgery 2002;131:S324-S329. 